\title{
Türk Kamu Örgütlerinde Kadın Yönetici Olmak: Gaziantep İli Örneği
}

\author{
DOI: $10.26466 /$ opus.550144 \\ *
}

\section{$\underline{\text { Esra Çımaz }}$}

* Dr. Öğr. Üyesi, Gaziantep Üniversitesi, İktisadi ve İdari Bilimler Fakültesi, 27000/ Gaziantep/ Türkiye

E-Posta: esracikmaz@gantep.edu.tr

ORCID:0000-0002-9576-7161

Öz

Bugün, kadınlar yaşamın her alanında yenilenmektedir. Toplumun kadına bakış açısı eskiye göre olumlu bir şekilde değişmektedir. Dolayısıyla, kadının istihdamdaki yeri değger kazanmaktadır. Bu durum kadınların bazı sorunları yaşamasına yol açmaktadır. Bu sorunlar, kadınları hayatın her alanında olduğu gibi iş yaşantısında da etkilemektedir. Yöneticilik görevini yerine getirme sürecinde, kadınlar çeşitli sorunlarla karşılaşmaktadır. Kadınların sorunlarının çözümlenmesi ülke ekonomisine sağlayacakları katkıyı arttırmaktadır. Bu doğrultuda, kadın yöneticilerin gelişimine yönelik araştırmaların yapılması önem arz etmektedir. Araştırmada, Türk kamu örgütlerinde kadınların yöneticilik görevini yerine getirme sürecinde karşılaştıkları sorunlar belirlenmektedir. Kamuda görev yapan kadın yöneticiler ile mülakatlar yapılarak, araştırmanın verilerine ulaşılmıştır. Araştırmanın veri toplama sürecinde, görüşme formları numaralandırılmış bir şekilde hazırlanarak, Gaziantep ilinde kamu kurum ve kuruluşlarında yönetici pozisyonunda görev yapan 35 kadın ile görüşülmüştür. Araştırma kapsamında, görüşme formunda hazırlanan sorular niteliksel derinliği ölçmeye ilişkin olduğundan açık uçlu olarak, değişkenlerin ilk olarak "ne olduğunu" anlamaya yönelik hazırlanmıştır. Veriler, istatistiksel bir program olan MAXQDA ile değerlendirilmiştir. 2018 yılında gerçekleştirilen görüşmelerin sonucunda, 77 ifade bulunmuştur. Araştırmanın sonucunda, kamudaki kadın yöneticilerin karşılaştıkları sorunlar belirlenmiştir. Bu sorunlar; psikolojik, sosyo-kültürel ve çevresel faktörlerden kaynaklanan sorunlar olmak üzere toplam 3 başlık olarak ortaya çıkarılmışıır. Bulgulara ait tüm sorunlar ayrıntılı bir şekilde değerlendirilmiştir. Buradan yola çıkarak, Türk kamu yönetimine katkı sağlanması amaçlanmıştır.

Anahtar Kelimeler: Türk Kamu örgütleri, Kadın yönetici, Sorunlar 


\title{
To Be A Women Administrator in Turkish Public Organizations: Gaziantep Sample
}

\begin{abstract}
Today, women are renewed in every aspect of life. Women's perspective on society changes in a positive way compared to the past. Therefore, the place of women in employment gains value. This situation causes women to have some problems. These problems affect women in business life as well as in every aspect of life. In the process of women's managerial duty, women managers face various problems. Analyzing the problems of women increases their contribution to the national economy. In this respect, it is important to conduct research on the development of women managers. In the research, the problems faced by women in the process of performing managerial duties in Turkish public organizations are determined. The interviews were conducted with the women managers working in the public sector and the data of the research was reached. In the data collection process of the study, the interview forms were prepared in a numbered manner and 35 women who were working in managerial positions in public institutions and organizations in Gaziantep were interviewed. Within the scope of the research, since the questions prepared in the interview form were about measuring the qualitative depth, it was prepared to understand the open-ended the variables firstly. The data were evaluated with a statistical program, $M A X Q D A$. As a result of the interviews held in 2018, 77 statements were found. As a result of the research, the problems faced by the women managers in the public sector were determined. These problems have been identified as 3 headings as phychological, socio-cultural and environmental factors. All problems of the findings were evaluated in detail. From this point of view, it is aimed to contribute to Turkish public administration
\end{abstract}

Keywords: Turkish public organizations, Women manager, Problems 


\section{Giriş}

Kadınlar, gerek dünyada gerekse de Türkiye' de nüfusun yaklaşık olarak yarısını oluşturmaktadır. Fakat ekonomik faaliyetlere bakıldığında, bu oranda temsil imkanı bulamamışlardır. Bu durum toplumların kadına yükledikleri rollerden kaynaklanmaktadır. $\mathrm{Bu}$ duruma ilaveten, iş yaşantısının genel olarak erkek ağırlıklı belirlenmesi, kadının iş yaşantısında arka planda yer alması sonucunu da beraberinde getirmiştir (Kocacık ve Gökkaya 2005, s.195). Sanayi Devrimi ile beraber oluşan sosyal gelişmelere bağlı olarak toplumsal bakış açısı da değişmiştir. Bu bakış açısının değişmesiyle toplumlarda kadına yeni roller yüklenmiştir. Dolayısıyla, kadınlar iş yaşantısındaki yerini almıştır.

Kadın toplumun genel olarak kabul gördüğü rollerinin dışında iş yaşantısına başlayarak sahip olduğu temel özellikleri iş yaşantısında yansitmaya başlamıştır (Negiz ve Yemen, 2011, s.196). Sahip olduğu görevini yerine getirme isteği onu görevinde yükselterek "yönetici" pozisyonuna gelmesine vesile olmuştur. Bu durum, kadının kendisini en başta kendisine olmak üzere topluma da kanıtladığı bir durum olmuştur. Kadınların yöneticilik görevlerine gelme ve bu görevleri yürütme süreçleri onlar için önemli bir kazanımı oluşturmaktadır. Öte yandan bu durumla beraber birtakım sorunlarda gün yüzüne taşınmıştır. Kadınlar, yöneticilik görevlerini yerine getirme sürecinde çeşitli sorunlarla yüzleşmektedir. Bu sorunlar göz önüne alındığında, bu alanda araştırma yapılmasının önemi kolayca izlenebilecektir.

Araştırmanın odak noktasında yönetici kadınlar bulunmaktadır.Bu araştırmada ortaya konulması gereken problem cümlesi; Türk kamu örgütlerinde kadınların yöneticilik görevini yerine getirme sürecinde, karşılaştıkları sorunların tespit edilmesinin yönetici kadınların motivasyonlarını artırarak iş yaşantısında ne tür bir katkı sağladığı şeklinde ifade edilmektedir. Dolayısıyla araştırma kapsamında, Türk kamu örgütlerinde yöneticilik görevini yerine getirme sürecinde, kadınların karşılaştıkları sorunlar irdelenerek, bu sorunlara yönelik çözüm yollarının aranması amaçlanmıştır. Dolayısıyla, söz konusu sorunların çözümlenmesinin Türk kamu yönetiminde ülke ekonomisine sağlayacağı katkıyı artırması ve Türk toplumundaki kadınların gelişimine yön vereceği düşünülmektedir. 
Araştırmada söz konusu kadın yöneticilerin karşılaştıkları sorunlar, Gaziantep ili kapsamında yönetici kadınlara uygulanan nitel bir araştırma ile tamamlanmıştır.

Araştırmanın birinci bölümünde "Türkiye'de Kadın Yöneticiler" başlığ1 altında, kadının Türkiye'deki genel durumu irdelendikten sonra kadınların karşılaştıkları sorunların, yapısal özellikleri ve toplumsal niteliği genel olarak ele alınmıştır. Bu doğrultuda, kadınların tarihsel süreçte iş yaşantısına katılım payları incelenmiştir.

İkinci bölümünde, "Yöntem" başlığı altında, araştırmanın örneklemi, veri toplama araçları açıklanarak, veriler analiz edilmiş ve yorumlanmıştır. Analiz edilen veriler doğrultusunda ortaya çıkan bulgular, Kamu örgütlerindeki kadın yöneticilerin demografik özellikleri ile bilgilerine ve karşılaştıkları sorunları belirlemeye yönelik bulgular olmak üzere tespit edilmiştir. Kadınların yöneticilik görevlerini yerine getirme sürecinde karşılaştıkları sorunlar detaylı bir şekilde incelenmiştir. Son bölüm olan üçüncü bölümde ise araştırmanın sonucu belirtilerek, bu sonuçtan çıarılan önerilere yer verilmiştir.

\section{Türkiye'de Kadın Yöneticiler}

Ekonomik ve toplumsal yaşamın her alanında farklı rollerde yer edinen kadınların yönetim kademelerinde yeterince yer alamadıkları görülmektedir. Tarihsel süreç içerisinde erkeklerle birlikte, ama daha çok kendilerine biçilen rollere göre görevler üstlenen kadınlar ne yazık ki yok denecek kadar azdır. Bugüne gelene kadar bu alanda belli başlı ilerlemeler sağlanmış olsa da yeterli değildir. İş yaşantısında az sayıda da olsa yönetim kademelerinde bulunan kadınları alanda zor bir süreç beklemektedir (Çakınberk, 2011, s.237).

Türkiye'de kadınların iş yaşantısında karşılaştıkları sorunlar, ülkemizin geleneksel yapısını içermektedir. Toplum, kadına iş yaşantısında çalışma ve eğitim görme hakkını vermektedir (Çelebi, 1993, s.5). Lakin Türk ataerkil toplum yapısına ait geleneksel yaklaşım aile kurma ve sürdürme konusundaki eğilimin dışındaki iş yaşantısında rütbe ve konumların daha çok erkeği kapsadığı görüşünü benimsemektedir.

Kadınların iş yaşantısında yönetici görevine yükselme sürecinde cesaretli olmaları, onların kendi kararlarını vermeleri açısından önemlidir. 
Lakin, (Besler ve Oruç, 2010, s.18)'in yaptıkları çalışmada, Paternalizm gibi seçim özgürlüğünün kısıtlandığı ülkelerde söz konusu süreçte kadınların cesaretli olmalarının zor olduğu görüşü dikkat çekmektedir. Nitekim Türkiye, Hofstede'nin (1980, s.286) yaptı̆̆ 1 bir araştırmaya göre; paternalizm (ataerkil) eğilimleri yüksek olan bir ülkedir (Aycan, 2004, s.453). Dolayısıyla, Türkiye'de kadınların iş yaşantısında cesaretlendirilerek, çeşitli pozisyonlarda görev alması ve terfi ettirilerek yönetici pozisyonlarına gelmeleri gerekmektedir. Bu durum, ülkenin gelişmişliği açısından çok büyük bir önem teşkil etmekle beraber ülkedeki kadın istihdamının da artırılmasına zemin hazırlayacağı düşünülmektedir.

Holst ve Bush (2009), kadının iş yaşantısında terfi ederek yükselmesinin mümkün olmadığını belirtmiştir. Sonuçta yöneticilik de erkek işi olarak ifade edilerek, kadınların yönetici görevlerine gelmelerindeki süreçte bazı sorunlar ile karşı karşıya kaldıkları iddia edilmektedir (Acuner ve Sallan, 1993, s.79).

Tarihsel süreçte ve bugün ataerkil toplumsal yapı gözlemlendiğinde, kamu alanında kadına az yer verildiği görülmektedir. Buna ilaveten, kadının iş yaşantısındaki yerinin erkeği destekleyici olarak görülmesi niteliğindedir. Türkiye'de de bu benzer yapı sonucunda, kadınların kamu örgütlerinde az sayıda yer aldıkları gibi yöneticilik görevinde bulunmalarının da kısıtlı olduğu gözlenmektedir (Acuner ve Sallan, 1993, s.79).

Türkiye' de yöneticilik alanında kadınlara ilişkin sayısal veriler baz alındığında; Kamu Personeli Anketi (1992) sonuçlarına göre; 1990 yılında kamu çalışanlarının yaklaşık \% 32'sini kadınların oluşturduğunu, 1988 yılından itibaren ise kadınların yöneticilik görevlerinde bulunma oranının yaklaşı \% 8 olduğu görülmüştür (Acuner ve Sallan, 1993, s.79). Dolayısıyla, kadınların yöneticilik görevlerine gelmelerinde bazı sorunlar yaşadıkları ve bu sorunların neler olduğunun üzerinde durularak irdelenmesi gerekmektedir. Bu noktada; yapılan araştırmanın ilgili alan yazınına katkı sunması düşünülmektedir. Araştırmanın benzer araştırmalardan ayırt edici özelliği, veri toplama sürecinde kadınların yöneticilik görevlerini yerine getirme sürecinde bulunmuş olmalarıdır. 


\section{Yöntem}

Araştırmanın amacı, Türk kamu örgütlerinde kadınların yöneticilik görevini yerine getirme sürecinde, karşılaştıkları sorunları belirlemek ve bu sorunlar üzerinde çözüm yolları üretmektir. Keşifsel olarak tasarlanan araştırmanın verileri, kamu örgütlerindeki kadın yöneticiler ile gerçekleştirilen görüşmeleri içermektedir. Araştırmada detaylı bilgiye ulaşabilmek için içerik analizi yapılmıştır. Herbir soru kağıdı üzerinden görüşme formları ayrı olarak tasarlanarak değerlendirilmiştir. Nitel araştırma olduğundan görüşme formlarındaki sorular "açı uçlu" olarak tasarlanmıştır. Veriler, MAXQDA istatistiksel paket programına aktarılarak, elde edilmiştir. Görüşme formlarındaki sorulardan yola çıkarak, kamu örgütlerindeki kadın yöneticiler ile yapılan görüşmelerde yöneticilik görevlerine gelme süreçleri doğrultusunda oluşan zorlukların neler olduğu üzerinde durulmuştur.

Araştırma örneklemini Gaziantep'te kamusal alanda görev yapan yönetici kadınlar oluşturmaktadır. Örneklemde 35 yönetici bulunmaktadır. Nitel olarak yapılan çalışmalarda örneklem büyüklüğünün en az 15 olması gerekmektedir (Berg, 2001, s.120). Bu bilgilerden yola çıkarak, 35 kişiden oluşan bir mülakatın 77 yorum ifadesi ile örneklemin büyüklüğü içerik analizi açısından kabul edilebilir olduğu düşünülmektedir. Araştırmanın yöntem bölümünde katılımcıların demografik özellikleri, bilgileri ve sorunlarına ilişkin bulgulara değinilmiştir.

\section{Katılımcıların Demografik Özellikleri ve Bilgilerine İlişkin Bulgular}

Tablo 1. Katılımcıları Demografik Özellikleri ve Bilgileri

\begin{tabular}{llllcl}
\hline \multicolumn{7}{c}{ GENEL BİLGILER } \\
\hline Yaş Dağılımları & Sayı & $\mathbf{\%}$ & Eğitim Durumu & Sayı & $\%$ \\
\hline 26-33 Arası & 10 & 28,57 & Lise & 12 & 34,28 \\
34-41 Arası & 15 & 42,85 & Ön lisans & 8 & 22,85 \\
42 ve üstü & 10 & 28,57 & Lisans & 8 & 22,85 \\
& & & Yüksek lisans ve Doktora & 7 & 20 \\
\hline Medeni Durum & Sayı & $\mathbf{\%}$ & Gelir Düzeyi & Sayı & $\%$ \\
\hline Evli & 10 & 12,75 & 2500-3500 TL. & 5 & 14,28 \\
Bekar & 25 & 87,5 & 3500-4500 TL. & 20 & 57,14 \\
& & & 4500 TL. ve üzeri & 10 & 28,57 \\
\hline TOPLAM & 35 & $\mathbf{1 0 0}$ & TOPLAM & 35 & $\mathbf{1 0 0}$ \\
\hline
\end{tabular}


Tablo 1'de görüşme formunu yanitlayan katılımciların demografik özellikleri ve bilgileri görülmektedir.

İlgili tabloya göre, katılımcıların yaş dağılımları incelendiğinde; \% 42,85'i gibi büyük bir çoğunluğunun 34-41 yaş arasında olduğu görülmüştür. Ayrıca, katılımcıların \% 45,7 sinin ön lisans ve lisans mezunu olduğu, yüksek lisans ve doktora mezununun ise azınlıkta (\%20) olduğu dikkat çekmektedir. Katılımcıların medeni durumlarına bakıldığında, \% $10^{\prime}$ unun evli \%25'inin ise bekar olduğu görülmektedir. Katılımcıların gelir düzeylerine bakıldığında, \%57,14'ünün 3500-4500 TL gelire sahip oldukları görülmüştür.

\section{Kamu Örgütlerindeki Kadın Yöneticilerin Karşılaştıkları Sorunları Belir- lemeye Yönelik Bulgular}

Araştırma kapsamında, kadın yöneticiler tarafından temin edilen veriler MAXQDA istatistiksel program ile değerlendirilmiştir. Yönetici kadınların karşılaştıkları sorunların belirlenmesi; verilerin kodlanması, kodların düzenlenmesi, bulguların tanımlanması ve yorumlanması olmak üzere dört kategoride gerçekleştirilmiştir. Kamu örgütlerindeki kadın yöneticilerin karşılaştıkları sorunlar üç ana temada toplanmıştır. Buna göre; kamu örgütlerindeki kadın yöneticilerin yöneticilik görevlerine gelme süreçlerinde karşılaştıkları sorunların, psikolojik, sosyo-kültürel ve çevresel olduğu görülmüş ve Şekil 1'de gösterilmiştir.

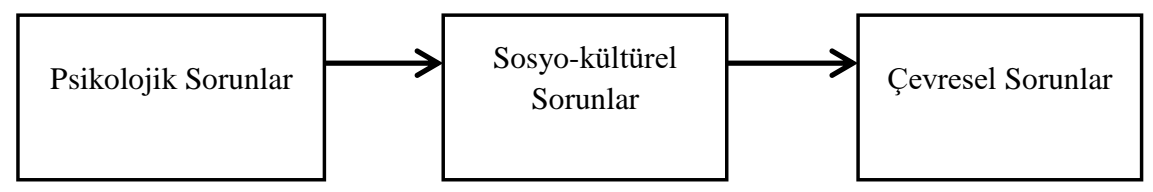

,Şekil 1. Kamu Örgütlerindeki Kadın Yöneticilerin Karşılaştıkları Sorunların Tematik Olarak Gruplandirilmast 


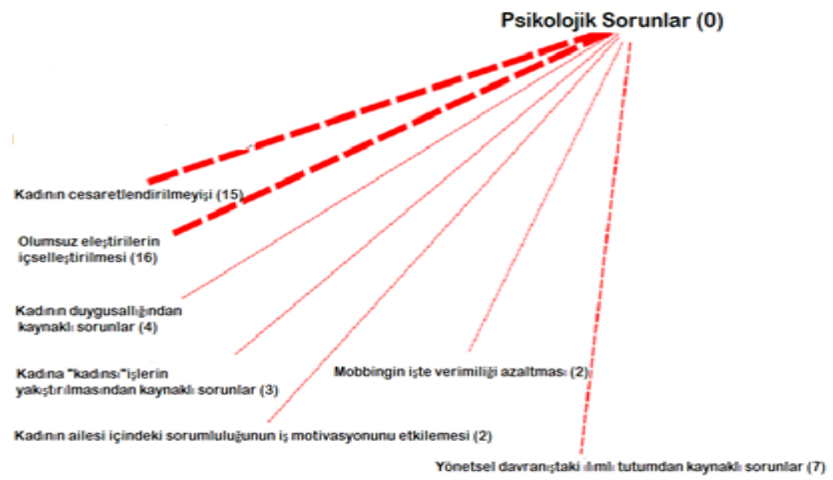

Şekil 2. Kamu Örgütlerindeki Kadın Yöneticilerin Karşılaştıkları Psikolojik Sorunların MAXQDA ile Değerlendirilmesi

Şekil 2 incelendiğinde; yöneticilik görevlerindeki kadınlardan 16 kişi gibi büyük bir çoğunluğun, iş yaşantısında kadınlarda yaşanan "olumsuz eleştirilerin içselleştirilmesi" nin sorun olduğunu belirttikleri görülmüştür. 15 kişi gibi arta kalan çoğunluğu ise "kadının cesaretlendirilmeyişi”" nin diğer bir sorun olduğunu belirtmiştir. Kadın yöneticilerin, "Yönetsel davranıştaki ılımlı tutumdan kaynaklı sorunlar", "kadının duygusallığından kaynaklı sorunlar", "kadına 'kadınsı' işlerin yakıştırılmasından kaynaklı sorunlar", "kadına ailesi içindeki sorumluluğunun iş motivasyonuna etkilemesi" ve "Mobbingin iş verimliliğini azaltması" gibi psikolojik olarak sınıflandırılan sorunlar yaşadıklarını belirttikleri söz konusu şekilde görülmektedir.

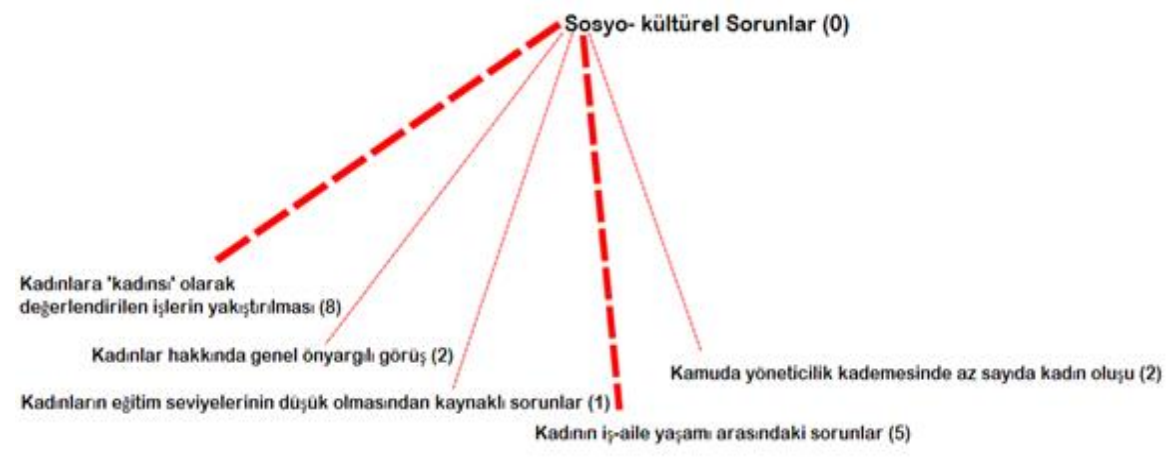

Şekil 3. Kamu Örgütlerindeki Kadın Yöneticilerin Karşılaştıkları Sosyo-kültürel Sorunların MAXQDA ile Değerlendirilmesi 
Şekil 3 incelendiğinde; yöneticilik görevlerindeki kadınlardan 8 kişi gibi büyük bir çoğunluğun, "kadınlara 'kadınsı' olarak değerlendirilen işlerin yakıştırılması" nın sorun olduğunu belirttikleri görülmüştür. 5 kişi ise "kadının iş-aile yaşamı arasındaki sorunlar" yaşamasının diğer bir sorun olduğunu belirtmiştir. Bununla birlikte, kadın yöneticilerin "kadınlar hakkında genel önyargılı görüş", "kadınların eğitim seviyelerinin düşük olmasından kaynaklı sorunlar" ile "kamuda yöneticilik kademesinde az sayıda kadın oluşu" gibi sosyo-kültürel olarak sınıflandırılan sorunlar yaşadıklarını belirttikleri söz konusu şekilde görülmektedir.

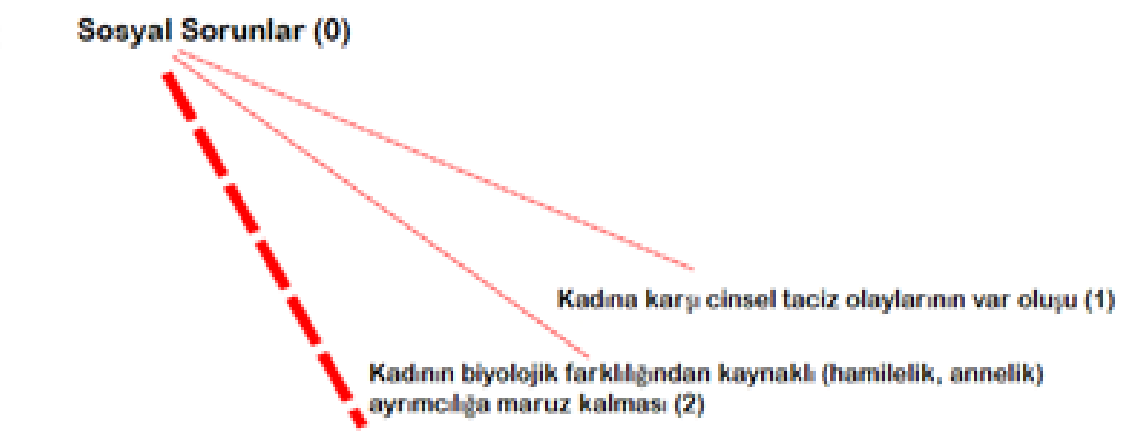

Kadinn statusunden kaynakh ( on, prestij vb.) sorunlar ( 7 )

Şekil 4. Kamu Örgütlerindeki Kadın Yöneticilerin Karşılaştıkları Çevresel Sorunların MAXQDA ile Değerlendirilmesi

Şekil 4 incelendiğinde; yöneticilik görevlerindeki kadınlardan 7 kişinin, "kadının statüsünden kaynaklı (ün, prestij vb.) sorunlar" in olduğunu belirttikleri görülmüştür. 2 kişi "kadının biyolojik farklılığından kaynaklı (hamilelik, annelik) ayrımcılığa maruz kalması" nın diğer bir sorun olduğunu belirtmiştir. Bununla birlikte, 1 kişi ise "kadına karşı cinsel taciz olaylarının var oluşu" nun diğer bir sorun olduğunu belirtmiştir.

\section{Sonuç ve Öneriler}

Toplumda kadınlar iş yaşantısına katılarak bağımsızlık ve kabul edilme arzularını gidermektedir. Kadınlar yeteneklerini sergileyebilecekleri 
ilgileri doğrultusundaki işlere odaklanarak gelir, idealleri gerçekleştirme, saygınlık kazanmayı hedeflemektedirler (Çakınberk, 2011, s.1). Kadınların iş yaşantısında elde edeceği başarılar ve özgüven hayatlarının diğer alanlarına da yansıyacaktır. Dolayısıyla, bu durum kadınlara başarı sağlayacağı gibi yaşamdan memnun olma hissini de kazandırmaktadır. Elde ettikleri gelir doğrultusunda kadınların özgüven sahibi olması, toplumda "ben de varım" demelerini sağlayacaktır (Yıldırım ve Çıkmaz, 2016, s. 977). Kadının görevini yerine getirme isteği artarak, ona özgüven kazandıracaktır. İş yaşantısında kadının özgüvenli olması işinde ilerlemeyi sağlayarak, kadının kariyerinde yükselmesini ve yönetici pozisyonunda görev almasını kolaylaştıracaktır. Bu bağlamda, kadının iş yaşantısında yöneticilik pozisyonunda yer alması, ülkenin sosyal ve ekonomik olarak gelişmişlik seviyesini artırmaktadır. Öte yandan, bu durumla beraber birtakım sorunlarla karşılaşılmıştır. Kadınlar, yöneticilik görevlerini yerine getirme sürecinde çeşitli sorunlarla yüzleşmektedir. Bu sorunlar göz önüne alındığında, bu alanda araştırma yapılmasının önemi kolayca izlenebilmektedir. Dolayısıyla, kadın yöneticilerin görevlerinde gelişerek, başarıyı yakalamaları için onların cesaretlendirilmeleri ve desteklenmeleri gerekmektedir.

Kamu örgütlerinde yönetici kadınlar üzerinde gerçekleştirilen bu araştırmada, yönetici kadınların karşılaştıkları sorunlar ayrıntılı bir şekilde değerlendirilerek, bu sorunlara yönelik çözüm yollarının aranması amaçlanmıştır. Dolayısıyla, söz konusu sorunların çözümlenmesinin Türk kamu yönetiminde ülke ekonomisine sağlayacağı katkıyı artırması ve Türk toplumundaki kadınların gelişimine yön vereceği düşünülmektedir. Araştırmada söz konusu kadın yöneticilerin karşılaştıkları sorunlar, Gaziantep ili kapsamında yönetici kadınlara uygulanan nitel bir araştırma ile tamamlanmıştır. Araştırmanın bulgularından hareketle sonuçları aşağıda sıralı bir şekilde gösterilmiştir.

Türk kamu örgütlerinde kadınların yöneticilik görevini yerine getirme sürecinde karşılaştıkları sorunlar üç bileşen altında toplanarak, 15 ifade altında belirlenmiştir. "Psikolojik Sorunlar Bileşeni", "Sosyo-kültürel Sorunlar Bileşeni" ve "Çevresel Sorunlar Bileşeni" olmak üzere ifadelerin 3 bileşen altında toplandığı ve toplam 77 sorun ifadesine vurgu yapıldığı görülmektedir. Kadın yöneticilerin kamu örgütlerinde yöneticilik 
görevlerini yerine getirme süreçlerinde en fazla sorunun psikolojik sorunlarda olduğu görülmüştür.

Yönetici kadınların kamu örgütlerinde karşılaştıkları psikolojik sorunlara bakıldığında; toplumun kadınlara yönelik olumsuz eleştiri yapmasının, onları cesaretlendirmeyişinin bir sorun olduğu söylenebilir. Bununla birlikte, kadın yöneticilerin, yönetsel davranıştaki ılımlı tutumlarından ve duygusallığından kaynaklı olarak psikolojik sorunlar yaşadıkları yorumu yapılabilir. Ayrıca, kadına sadece kadınsı işlerin yakıştırılmasının diğer bir psikolojik sorun olduğu söylenebilir.

Yönetici kadınların kamu örgütlerinde karşılaştıkları sosyo-kültürel sorunlara bakıldığında; kadına sadece kadınsı işlerin yakıştırılmasının, işaile arasında kadının kalmasına zemin hazırladığı söylenebilir. Ayrıca, kamusal alanda az sayıda kadın yöneticinin olması ise diğer bir sorundur. Genel olarak bakıldığında, yönetici kadınların eğitim seviyesinin düşük olmasının ise iş verimini azalttığı düşünülmektedir.

Yönetici kadınların kamu örgütlerinde karşılaştıkları çevresel sorunlara bakıldığında; kadının statüsünden kaynaklı olan ün, prestij, imajdan kaynaklı sorunlar, biyolojik farklılı̆̆ından kaynaklı (hamilelik, annelik gibi) sorunların kadının ayrımcılığa maruz kalmasını düşündürebilir. Ayrıca, kadına karşı cinsel taciz olaylarının var oluşunun bu sorunlara bağlı diğer sorunlar yaşattığı söylenebilir. Bu sonuçlar incelendiğinde; toplumun bilinçlendirilmesi sayesinde, kadın yöneticilerin psikolojik, sosyo-kültürel ve çevresel anlamda desteklenerek, yöneticilik pozisyonunda istihdamının gerek kamusal alanda gerekse de özel sektörde artırılmasının, Türkiye'nin bölgesel ve küresel anlamda zemin hazırlayacağı düşünülmektedir.

Araştırma sonuçları genel olarak değerlendirildiğinde; kamu örgütlerinde kadın yönetici olmanın birtakım sorunları beraberinde getirdiği görülmüştür. Başka bir ifade ile yönetici kadınların kamusal alanda yaşadıkları psikolojik, sosyo-kültürel ve çevresel sorunların onları iş yaşantısında olumsuz yönde etkilediği bu araştırma ile ortaya konmuştur. Bununla beraber ileride yapılacak araştırmalar için örneklemin daha geniş tutulması, çeşitli bölgelerde ve ülkelerde kıyaslamalı olarak yapılması önerilebilir. Benzer olarak yapılacak çalışmalarda nicel yöntemin uygulanması tavsiye edilebilir. 


\title{
EXTENDED ABSTRACT
}

\section{To Be A Women Administrator in Turkish Public Organizations: Gaziantep Sample}

\author{
Esra Çıkmaz
}

Gaziantep University

It is observed that women who take place in different roles in all areas of economic and social life cannot take place in management levels enough. In the historical process, unfortunately, there are almost no women with men, but rather those who assume tasks according to the roles assigned to them. Until today, although major advances have been made in this area, it is not enough. Even though a small number of women are in business life, a difficult process is expected in the field. The social perspective has changed due to the social developments that occurred with the Industrial Revolution (Çakınberk, 2011, p.237). With the change of this perspective, women have new roles in societies. Therefore, women have taken their place in business life.

Women have started to reflect the basic characteristics they have in business life starting with their business life (Negiz and Yemen, 2011, p.196). Her intention to fulfill her task has led her to take up her position in the position of "manager". This situation has been a situation where the woman has proved herself to the society first and foremost to herself. The process of women's participation in executive positions and the execution of these tasks constitutes an important gain for them. On the other hand, with this situation, some problems have been carried to the face of the day. Women face various problems in the process of performing their managerial duties. Given these problems, the importance of conducting research in this area can be easily monitored.

The focus of the research is on executive women. In the process of carrying out the managerial duties of women in Turkish public organizations, it is stated that identifying the problems they face is contributing to 
the work life by increasing the motivation of the women. Therefore, within the scope of the research, in the process of performing administrative duties in Turkish public organizations, the problems faced by women are examined and it is aimed to search for solutions to these problems. Therefore, it is thought that the resolution of these problems will increase the contribution to the national economy in Turkish public administration and will lead to the development of women in Turkish society. In the study, the problems faced by these women managers were completed with a qualitative research applied to women in the province of Gaziantep. Holst and Bush (2009) stated that it is not possible for a woman to be promoted in business life. As a result, managerialism is expressed as a male job and it is claimed that women are faced with some problems in the process of coming to the executive positions.

When the patriarchal social structure is observed in the historical process and today, it is seen that women are given little space in the public domain. In addition, the position of women in business life is considered to be supportive of men. In Turkey, this structure similar results, as they take place in the presence of a small number of managerial positions in women's public organizations are observed to be restricted. Therefore, women have some problems in coming to their managerial positions and they need to be examined by considering these problems. At this point; it is thought that the research will contribute to the related literature. The distinctive feature of the research is that women have been in the process of carrying out their managerial duties in the data collection process.

Qualitative method was used in the research. The data of the exploration study, which is designed as exploratory, includes interviews with women managers in public organizations. In order to reach detailed information, content analysis was performed. Interview forms were evaluated and evaluated separately from each questionnaire. As it is qualitative research, questions in interview forms are designed as open-ended. Data were transferred to the MAXQDA statistical package program. Based on the questions in the interview forms, it was emphasized that the difficulties that occur in the direction of the management processes in the meetings with the women managers in public organizations are discussed. The research sample consists of the executive women working in public sector in Gaziantep. There are 35 managers in the sample. The findings of 
the study were evaluated in two categories as demographic characteristics, information and problems of the participants. As a result, in this study conducted on executive women in public organizations, the problems faced by executive women were evaluated in detail and it was aimed to search for solutions to these problems. Therefore, it is thought that the resolution of these problems will increase the contribution to the national economy in Turkish public administration and will lead to the development of women in Turkish society. In general, it has been seen that being a female manager in public organizations brings some problems. In other words, the psychological, socio-cultural and environmental problems experienced by the women in the public domain have been negatively affected by the research. However, it may be suggested that the sample should be made more broadly in comparison with other regions and countries. Similarly, it is advisable to apply quantitative method in the studies.

\section{Kaynakça / References}

Acuner, S. ve Sallan, S. (1993). Türk kamu yönetiminde yönetici kadınlar. Amme İdaresi Dergisi, 26(3), 77-92.

Aycan, Z. (2004). Üç boyutlu cam tavan: Kadınların kariyer gelişiminde kim, kime, neden engel oluyor? 2. Kadın Yöneticiler Zirvesi, 2004, İstanbul.

Berg, B, L. (2007). Qualitative research methods for the social sciences. Boston: Pearson/Allyn \& Bacon.

Besler, S., Oruç, İ. (2010). Türkiye'de yazılı basında kadın yöneticiler. Anadolu Üniversitesi, Sosyal Bilimler Dergisi, 10(1), 17-38.

Çakınberk, A.(2011). Iş̧'te kadın olmak (1.Bask1). Ankara: Nobel yayıncılık.

Çelebi, N. (1993). Kadın Girişimciliğini Özendirme ve Destekleme Konusunda Politikalar, Kadını Girişimciliğe Özendirme ve Destekleme Paneli Bildiriler ve Tartışmalar, Devlet Bakanlığı Kadın Ve Sosyal Hizmetler Müsteşarlığı Kadının Statüsü ve Sorunları Genel Müdürlüğ̈̈ Ĕ̆itim Serisi, 74, 35-42.

Çıkmaz, E.(2018). Kamu destekleri aşamasında kadın girişimcilerin karşılaştıkları sorunlara yönelik yol analizi. ASSAM Uluslararası Hakemli Dergi (ASSAM - UHAD), 11, 44-49.

Kocacık, F. ve Gökkaya, B. V. (2005). Türkiye'de çalışan kadınlar ve sorunları, C.Ü. İktisadi ve İdari Bilimler Dergisi, 6(1), 195. 
Hoftstede, G.(1980). Culture's consequences: International differences in workrelated values, Newbury Park:sage Publications Inc.

Holst,E. ve Bush, A. (2009). Glass Ceiling Effect and Earnings: The Gender Pay Gap in Managerial Positions in Germany. Soap Papers 201, DIW Berlin, The German Socio-Economic Panel (SOEP), (2009),Berlin.

Negiz, N. ve Yemen, A. (2011). Kamu örgütlerinde kadın yöneticiler: yönetici ve çalışan açısından yönetimde kadın sorunsalı, SDÜ Fen Edebiyat Fakültesi Sosyal Bilimler Dergisi, 24, 195-214.

Şencan, H.(2005).Sosyal ve davranışsal ölçümlerde güvenilirlik ve geçerlilik. Ankara: Seçkin Yayıncılık.

Tambunan, T. (2009). Women Entrepreneurship in Asian Developing Countries: Their Development and Main Constraints. Journal of Development and Agricultural Economics.1(2), 27-40.

Thornton, P.H., Ocasio, W. (1999), Institutional logics and the historical contingency of power in organizations: Executive sucession in the higher education publishing industry, American Journal of Sociology, 105(3), 801-843.

Yıldırım, İ. ve Çıkmaz, E. (2016). Kadın girişimcilerin, kamu kurum ve kuruluşlarından destek alma sürecinde karşılaştıkları sorunlar: Gaziantep ilinde nitel bir değerlendirme. Uluslararası Sosyal Araştırmalar Dergisi, 9(47), 977-985.

\section{Kaynakça Bilgisi / Citation Information}

Ç1kmaz, E. (2019). Türk kamu örgütlerinde kadın yönetici olmak: Gaziantep ili örneği. OPUS-Uluslararası Toplum Araştırmaları Dergisi, 11(18), 785-799. DOI: 10.26466/opus.550144 